\title{
Intraplant variation in secondary metabolite concentration in three species of Caulerpa (Chlorophyta: Caulerpales) and its effects on herbivorous fishes
}

\author{
Karen D. Meyer, Valerie J. Paul \\ University of Guam Marine Laboratory, UOG Station, Mangilao, Guam 96923, USA
}

\begin{abstract}
Three species of tropical green algae, Caulerpa spp., were examined for intraspecific variation in the concentrations of their secondary metabolites. Individual plants were collected from coral reef areas on Guam, divided into 2 plant portions (uprights and runners), and extracted separately. We hypothesized that secondary metabolite concentration would be higher in the uprights than the runners of the plant, because the uprights are more exposed to macroherbivores and are involved in reproduction. All 3 species, $C$. sertularioides, $C$. racemosa, and C. cupressoides, contained higher concentrations of crude organic extracts and the major secondary metabolite, caulerpenyne, in the uprights than in the runners. Although all 3 Caulerpa spp. showed the predicted pattern of variation in the concentration of caulerpenyne, results from the feeding studies showed that the crude extracts and isolated metabolites, caulerpenyne and caulerpin, did not act to deter feeding by herbivorous fishes, even at the highest natural concentrations
\end{abstract}

\section{INTRODUCTION}

Herbivory has a major impact on the structure and function of tropical marine communities (Ogden \& Lobel 1978, Birkeland et al. 1985, Morrison 1988, Horn 1989). For example, it has been shown that $97 \%$ of the annual algal turf was removed by herbivores in the back reef/reef crest habitat of St. Croix, US Virgin Islands (Carpenter 1986). As a result, marine plants must be able to escape, tolerate or deter herbivores (Hay \& Fenical 1988). At least 3 ways have been identified in which seaweeds can minimize the effect of grazing: (1) rapid growth followed by reproduction, (2) production of cells which are hard, and (3) production of chemicals which are unpalatable (Lobban et al. 1985). Of course, a plant is not limited to one defense. It is highly possible that a suite of defenses are used against herbivores. Of these 3 , however, the production of secondary chemicals by seaweeds has received the most attention.

Few chemical studies have accurately quantified the amounts of compounds (Hay \& Fenical 1988). If yields are listed, they are based on mass extractions of numer- ous plants and ignore potential variation within or between individuals. As a result, the concentrations reported may not be indicative of quantities encountered by herbivores in the environment

Intraspecific variation in the concentration of secondary metabolites could theoretically occur in several ways: (1) variation within different parts of the same plant (e.g. tips vs bases), (2) variation between individual plants in the same population, (3) variation between habitats, and (4) seasonal (temporal) variation (e.g. reproductive vs non-reproductive).

A few studies have looked at intraspecific variation in the production of secondary metabolites in algae (Ragan \& Jensen 1978, Phillips \& Towers 1982, Steinberg 1984, Gerwick et al. 1985, Paul \& Van Alstyne 1988, Van Alstyne 1988, Carlson et al. 1989, Steinberg 1989, Tugwell \& Branch 1989). These studies found considerable intraspecific variation in secondary metabolite production. The green alga, Halimeda macroloba, contained more of the secondary metabolite halimedatrial in newly produced, uncalcified segments than in older, calcified segments (Hay et al. 1988, Paul \& Van Alstyne 1988). Another secondary metabolite, 
halimedatetraacetate, was more abundant in the older segments. Halimedatrial was more deterrent toward field populations of herbivores than halimedatetraacetate (Paul \& Van Alstyne 1988). Phillips \& Towers (1982) studied variation of lanosol levels in the red alga, Rhodomela larix (Turner) C. Agardh. They found slight variations in lanosol levels between populations, with considerably higher levels in those plants growing in tidepool areas. Slight differences in lanosol production also occurred within the thallus of individual plants: the younger, growing areas of the thallus produced more lanosol than the holdfast (Phillips \& Towers 1982, Carlson et al. 1989). The brown alga Fucus distichus increased the concentrations of its varied phenolic compounds by approximately $20 \%$ after being experimentally injured (Van Alstyne 1988). This increase in concentration of metabolites occurred over a 2 wk period. The herbivorous snail Littorina sitkana shifted its preference from injured plants to uninjured control plants over a 2 wk period (Van Alstyne 1988).

Within the green algae, only 2 studies (Hay et al. 1988, Paul \& Van Alstyne 1988) on Halimeda spp. have examined intraspecific variation in the concentration of secondary metabolites. This study addresses 2 major questions: (1) Is there intraspecific variation in the concentration of secondary metabolites in 3 species of green algae, Caulerpa racemosa (Forskaal) J. Agardh, C. cupressoides (Vahl) C. Agardh, and C. sertularioides (Gmelin) Howe, among individuals in a given habitat, or within different portions of the same plant? (2) If this variation occurs, how does this relate to levels of grazing by natural populations of herbivorous fishes?

\section{MATERIALS AND METHODS}

Chemical analyses. Three species of the Chlorophyceae (Caulerpa sertularioides, C. racemosa, and C. cupressoides) were collected at sites around the island of Guam $\left(13^{\circ} 25^{\prime} \mathrm{N}, 144^{\circ} 55^{\prime} \mathrm{E}\right)$ where the algae were found to be abundant. Extractions were done as soon as possible after collection, usually within $4 \mathrm{~h}$. The 3 species of Caulerpa used in this study all exhibit upright blades, with the rhizomes and rhizoids anchoring the plant in sand or rubble. Plant growth is sometimes dense, making it difficult to identify individuals. In an attempt to sample genetically individual plants, individuals that were collected were at least $20 \mathrm{~m}$ apart. C. sertularioides was found only in an isolated patch on the sand bottom of Piti Channel (August 1990. $\mathrm{N}=10$ ). Since they were growing in 1 area, individuals of this species will be referred to as ramets, individual plants derived either by growing from a sexually produced seed or from vegetative production (Walker 1989). C. racemosa (May and August 1990, $N=10$ for each collection) and C. cupressoides (July 1989, $N=6$; November 1989, $\mathrm{N}=14$; October 1990, $\mathrm{N}=10$ ) were collected in Cocos Lagoon approximately $30 \mathrm{~m}$ offshore ( 1 to $2 \mathrm{~m}$ deep) on the northwest side of Cocos Island. C. racemosa was also collected in a sandy mangrove area off Grand Bahama Island, Bahamas, in July 1990 $(N=10)$. Individual plants were extracted separately unless a large quantity of extract was needed for fish feeding preference assays. Individuals were divided into uprights (vertical portion) and runners (horizontal portion). Extractions were done in a $1: 1$ mixture of methanol: dichloromethane and each plant portion was extracted exhaustively (usually 3 times was adequate) after being ground with a Virtis tissue homogenizer. Yields are based on mass of extract per dry mass of the plant.

Quantitative analyses focused on the compound caulerpenyne (Fig. 1). Previous studies have shown this

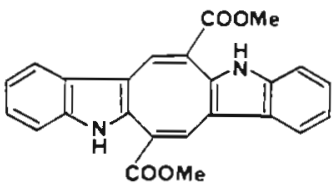

CAULERPIN

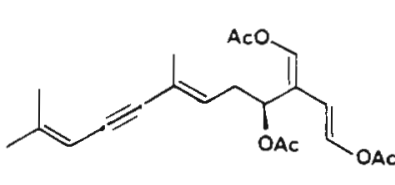

CAULERPENYNE
Fig. 1. Caulerpa spp. Molecular structures of the isolated metabolites found in the algae extracts

compound, as well as a second compound called caulerpin (Fig. 1), to be the major components of Caulerpa spp. organic extracts (Paul 1985, Paul \& Fenical 1986). However, past work has shown that caulerpin has no deterrent effect on herbivores (McConnell et al. 1982, Paul et al. 1987. Wylie \& Paul 1988, Pennings \& Paul in press). Therefore, focus was placed on the potentially biologically active caulerpenyne (Paul \& Fenical 1986, Targett et al. 1986). However, in order to account for all possible secondary metabolites that may be present in Caulerpa spp., crude extracts, as well as purified caulerpenyne, were tested as feeding deterrents toward herbivores.

Qualitative analyses of the extracts were done using thin layer chromatography (TLC) on commercially prepared silica plates (EM Science, Kieselgel $60 \quad \mathrm{~F}_{254}$ ). Quantitative analyses of the pure compounds making up the crude organic extracts involved the use of a Beckman high performance liquid chromatography (HPLC) instrument with integrator. The HPLC consisted of a Beckman model $110 \mathrm{~B}$ solvent pump with an Alltech $25 \mathrm{~cm} \times 4.6 \mathrm{~mm}$ Spherisorb $5 \mu \mathrm{m}$ silica column. The injection loop was $20 \mu \mathrm{l}$ in size. All samples were diluted to $10 \mathrm{mg} 100 \mu \mathrm{l}^{-1}$, with an injection of $20 \mu \mathrm{l}$. The mobile phase and dilution solvent for all Caulerpa 
samples was a $25 \%$ ethyl acetate/75\% hexane mixture. Peak areas were measured by automatic electronic integration. The peak of interest was identified by injection of a previously purified (by HPLC) standard of caulerpenyne at varying concentrations to determine a standard curve. Samples were then adjusted to fall within the linear section of the standard curve.

In data analysis, all yield comparisons were arcsine (square root) transformed since raw data were percentages which were outside the 30 to $70 \%$ range (Sokal \& Rohlf 1981). This also adjusted the data so that it conformed to the assumptions (normality and homogeneity of variances) of analysis of variance. Upright yields were compared to runner yields using a paired t-test (Sokal \& Rohlf 1981). A nested analysis of variance was used to compare yields in those species with more than 1 date of collection. In this analysis, plant part (fixed factor) was nested within plant (random factor), and plants were replicates for the dates (random factor). In the case of Caulerpa cupressoides, a table of random numbers was used to reduce the sample size (Sokal \& Rohlf 1981) in the latter 2 dates of collection (November 1989, $\mathrm{N}=14$ and October 1990, $\mathrm{N}=10$ ) to equal the July 1989 sample size $(N=6)$ for the ANOVA computations.

Feeding preference assays. Feeding preference assays using the organic extracts and associated pure compounds were conducted on a patch reef in Cocos Lagooon, Guam (also described in Paul 1987). This patch reef averages 1 to $4 \mathrm{~m}$ in depth and contains a variety of herbivorous fishes. Among the most common fishes seen on the reef are juvenile Scarus sordidus, while Amblyglyphidodon curacao, Naso lituratus, Zebrasoma flavescens and Siganus argenteus also commonly occur on the reef and were observed to feed during the assays. Other fish observed feeding in this area include Chaetodon kleinii and Cheilinus fasciatus.

The assays were used to test the high and low range of extract yields (based on percent organic extract per dry mass of the plant) of each alga, as well as the different concentrations of pure compounds (within the natural range) making up the crude extracts. Preliminary studies used algal pieces coated with pure compounds. These methods have previously been described (Paul 1987, Paul \& Van Alstyne 1988, Wylie \& Paul 1988). Briefly, small pieces of the palatable green seaweed Enteromorpha clathrata (approximately $250 \mathrm{mg}$ wet mass) were coated with a solution of pure compound (caulerpenyne or caulerpin) dissolved in organic solvent (diethyl ether or acetone). The feeding ropes consisted of $0.5 \mathrm{~m}$ long, 3-stranded yellow polyprophylene rope. Four E. clathrata treated pieces were entwined on one rope and paired with 4 control pieces (solvent coated) on a second rope. When the food was approximately half eaten, these assays were scored as number of pieces completely eaten and were analyzed using the Wilcoxon signed rank test for paired comparisons (Sokal \& Rohlf 1981).

Most assays involved using large amounts of extract due to the high crude extract yields of the plants. To ensure that the chemical would be adequately mixed in the food, an artificial diet was used to conduct the assays, with any extracts or pure metabolites incorporated into the diet. The diet consisted of ground fish pellets ( $2.5 \mathrm{~g}$ Kruses's Perfection Brand, available from O. H. Kruse Grain and Milling, El Monte, CA), along with wax $(2 \mathrm{~g})$, carrageenan $(2.5 \mathrm{~g})$, and water $(70 \mathrm{ml})$ to form a somewhat stiff food that did not dissolve in water. Any compounds to be tested were dissolved in a known quantity of solvent (usually acetone or dichloromethane) and added to the food mixture, with the controls containing the same amount of solvent. Separate feeding assays testing the effects of solvent vs control (no solvent) showed no effect of the solvent on feeding.

The diet, along with any compounds or extracts to be tested, were molded into cubes (approximately $1 \mathrm{~cm}^{3}$ in size) with a small rubber O-ring embedded in the food. This O-ring enabled the food to be attached to a rope. In the assays which used the artificial food, 4 safety pins were attached to the upper portion of each rope, each with 1 piece of neoprene (about $1 \mathrm{~cm}^{3}$ ). These neoprene cubes helped hold the food cube away from the rope, allowing fish access from all directions. The food for each rope (4 pieces) was weighed before being placed on the rope. Each replicate consisted of a pair of ropes. Each of 10 to 20 replicate pairs of ropes were placed along the reef for a period of time until approximately half the food was eaten (1 to $4 \mathrm{~h}$ ). At that time, each rope was placed in an individual bag and transported back to the lab. Food cubes were removed from the ropes and re-weighed. A set of ungrazed ropes was also placed on the reef at the same time to account for weight change due to handling or time in the water. Analysis involved a matched pairs $t$-test, with data entered as amount eaten (Sokal \& Rohlf 1981). The matched pairs $t$-test compared the amount eaten of each of the 2 ropes; however, this did not provide a direct comparison between the different sets of ropes. Those treatments which we wished to compare were assayed at the same time on the same day.

There were several assumptions made in the types of assays utilized in this study. First, we assumed that during the course of the assays, the fishes' perception and hunger remained relatively constant. Social interactions were also assumed to have no significant effect on the assays. Lastly, as Lewis (1986) observed in her study, grazing may vary on a microhabitat scale, which could be affecting the assays. Regardless, these 
Table 1. Caulerpa spp. Crude extract yelds from individual plants. Yields are measured as percent organic soluble materials per plant dry mass. Paired t-tests were performed on arcsine square root transformed data to compare uprights vs runners

\begin{tabular}{|c|c|c|c|c|c|c|c|}
\hline Species & Mean & Yield range & SE & N & Date & Site & p-value \\
\hline \multicolumn{8}{|c|}{ Caulerpa racemosa } \\
\hline $\begin{array}{l}\text { Uprights } \\
\text { Runners }\end{array}$ & $\begin{array}{r}10.07 \\
3.74\end{array}$ & $\begin{array}{l}7.26-12.93 \\
1.02-5.82\end{array}$ & $\begin{array}{l}0.65 \\
0.52\end{array}$ & $\begin{array}{l}10 \\
10\end{array}$ & May 1990 & Cocos lagoon & 0.001 \\
\hline $\begin{array}{l}\text { Uprights } \\
\text { Runners }\end{array}$ & $\begin{array}{l}7.39 \\
4.47\end{array}$ & $\begin{array}{l}5.02-12.63 \\
1.06-10.84\end{array}$ & $\begin{array}{l}0.77 \\
0.83\end{array}$ & $\begin{array}{l}10 \\
10\end{array}$ & Aug 1990 & Cocos lagoon & 0.007 \\
\hline $\begin{array}{l}\text { Uprights } \\
\text { Runners }\end{array}$ & $\begin{array}{r}12.55 \\
4.23\end{array}$ & $\begin{array}{l}7.73-18.79 \\
2.03-7.34\end{array}$ & $\begin{array}{l}1.07 \\
0.46\end{array}$ & $\begin{array}{l}10 \\
10\end{array}$ & Jul 1990 & $\begin{array}{l}\text { Grand Bahama } \\
\text { Island }\end{array}$ & 0.001 \\
\hline \multicolumn{8}{|c|}{ Caulerpa cupressoides } \\
\hline $\begin{array}{l}\text { Uprights } \\
\text { Runners }\end{array}$ & $\begin{array}{l}12.06 \\
15.97\end{array}$ & $\begin{array}{r}6.36-20.17 \\
10.21-24.82\end{array}$ & $\begin{array}{l}1.91 \\
2.08\end{array}$ & $\begin{array}{l}6 \\
6\end{array}$ & Jul 1989 & Cocos Lagoon & 0.069 \\
\hline $\begin{array}{l}\text { Uprights } \\
\text { Runners }\end{array}$ & $\begin{array}{l}6.51 \\
4.29\end{array}$ & $\begin{array}{l}2.53-10.31 \\
1.26-20.33\end{array}$ & $\begin{array}{l}0.58 \\
1.32\end{array}$ & $\begin{array}{l}14 \\
14\end{array}$ & Nov 1989 & Cocos Lagoon & 0.035 \\
\hline $\begin{array}{l}\text { Uprights } \\
\text { Runners }\end{array}$ & $\begin{array}{l}9.21 \\
2.22\end{array}$ & $\begin{array}{l}6.93-12.86 \\
0.98-3.51\end{array}$ & $\begin{array}{l}0.60 \\
0.26\end{array}$ & $\begin{array}{l}10 \\
10\end{array}$ & Oct 1990 & Cocos Lagoon & 0.001 \\
\hline \multicolumn{8}{|c|}{ Caulerpa sertularioides } \\
\hline $\begin{array}{l}\text { Uprights } \\
\text { Runners }\end{array}$ & $\begin{array}{l}21.08 \\
10.97\end{array}$ & $\begin{array}{r}15.57-28.11 \\
2.66-30.59\end{array}$ & $\begin{array}{l}1.38 \\
2.58\end{array}$ & $\begin{array}{l}10 \\
10\end{array}$ & Aug 1990 & Piti Channel & 0.007 \\
\hline
\end{tabular}

feeding assays are still the best way to be able to control a diet and test the effects of secondary metabolites on natural populations of herbivorous fishes.

\section{RESULTS}

\section{Chemical analyses}

In all except one of the collections, Caulerpa spp. uprights produced significantly more organic soluble extract than runners (Table 1). Crude extract yields from the 2 collections of C. racemosa from Guam were compared using nested ANOVA (Table 2). Date did not affect yield, but plant part did significantly affect yield, corroborating the above analysis. The interaction term for Date $x$ Part was also significant, indicating that the degree of difference between plant parts varied between the 2 dates. Results for 3 collections of $C$. cupressoides were similar (Table 3), except that, for

Table 2. Caulerpa racemosa. ANOVA comparison of dates of collection and different plant parts. Data were arcsine (square root) transformed before analysis

\begin{tabular}{|lrlrl|}
\hline Source & df & MS & $F$ & p-value \\
\hline Date & 1 & 0.002898 & 0.84 & 0.3707 \\
Plant & & & & \\
Date $\times$ Plant & 18 & 0.003438 & & \\
Part & 1 & 0.09967 & 65.21 & 0.0001 \\
Date $\times$ Part & 1 & 0.01044 & 6.83 & 0.0176 \\
Date $\times$ Plant $\times$ Part & 18 & 0.001528 & & \\
\hline
\end{tabular}

this species, crude extract yields also varied significantly between dates.

Quantitative HPLC analysis showed that caulerpenyne production was variable between plant parts

Table 3. Caulerpa cupressoides. ANOVA comparison of dates of collection and different plant parts. Data were arcsine (square root) transformed before analysis

\begin{tabular}{|rrrrr|}
\hline Source & df & \multicolumn{1}{c}{ MS } & $F$ & p-value \\
\hline Date & 2 & 0.09375 & 24.92 & 0.0001 \\
Plant & & & & \\
Date $\times$ Plant & 15 & 0.003763 & & \\
Part & 1 & 0.0379 & 20.93 & 0.0004 \\
Date $\times$ Part & 2 & 0.0349 & 19.29 & 0.0001 \\
Date $\times$ Plant $\times$ Part & 15 & 0.001811 & & \\
\hline
\end{tabular}

(Table 4, Fig. 2). In all collections of Caulerpa spp. analyzed, uprights produced more caulerpenyne than runners. Excluding the Bahamas collection, caulerpenyne was higher both when measured as the percent of organic extract (Table 4) and as the percent of plant dry mass (Fig. 2). Therefore, the higher amount of caulerpenyne in the tips was not only the result of the higher extract yields of the tips, but a result of a higher percentage of caulerpenyne in the extracts as well.

\section{Feeding preference assays}

All 3 Caulerpa spp. crude extracts were tested in varying concentrations to determine levels of deter- 
Table 4. Caulerpa spp. Caulerpenyne yields (\% organic extract). Paired $t$-tests were performed on arcsine square root transformed data to compare uprights vs runners

\begin{tabular}{|c|c|c|c|c|c|}
\hline Species & Location & Mean yield $(\%)$ & Range $(\%)$ & SE & $\mathrm{p}$-value \\
\hline \multicolumn{6}{|c|}{ Caulerpa racemosa } \\
\hline $\begin{array}{l}\text { Uprights } \\
\text { Runners }\end{array}$ & Guam & $\begin{array}{l}9.95 \\
4.95\end{array}$ & $\begin{array}{l}4.17-15.81 \\
1.46-9.89\end{array}$ & $\begin{array}{l}0.88 \\
0.80\end{array}$ & 0.0035 \\
\hline $\begin{array}{l}\text { Uprights } \\
\text { Runners }\end{array}$ & Bahamas & $\begin{array}{l}13.15 \\
10.45\end{array}$ & $\begin{array}{l}3.54-33.45 \\
2.45-26.91\end{array}$ & $\begin{array}{l}3.06 \\
2.12\end{array}$ & 0.3864 \\
\hline $\begin{array}{l}\text { C. cupresso } \\
\text { Uprights } \\
\text { Runners }\end{array}$ & Guam & $\begin{array}{r}22.53 \\
8.33\end{array}$ & $\begin{array}{r}10.99-31.30 \\
4.66-20.36\end{array}$ & $\begin{array}{l}1.75 \\
1.35\end{array}$ & 0.001 \\
\hline $\begin{array}{c}\text { C. sertulari } \\
\text { Uprights } \\
\text { Runners }\end{array}$ & Guam & $\begin{array}{l}43.35 \\
20.55\end{array}$ & $\begin{array}{r}20.91-61.86 \\
6.70-32.39\end{array}$ & $\begin{array}{l}3.62 \\
2.92\end{array}$ & 0.0043 \\
\hline
\end{tabular}

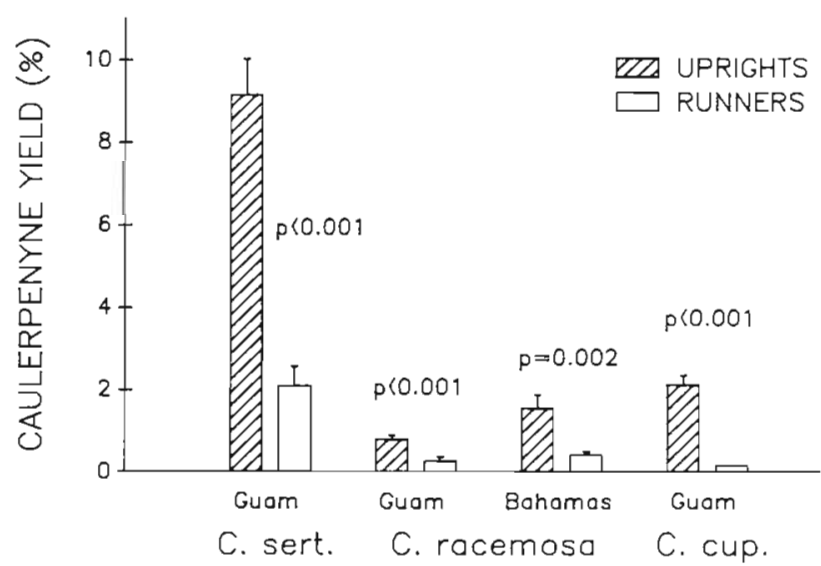

Fig. 2. Caulerpa spp. Mean caulerpenyne yield $1 \%$ of dry mass) of individual plant parts (C. sertularioides, C. racemosa and $C$. cupressoides) analyzed by quantitative HPLC. Vertical bars above each histogram represent +1 SE. Data were analyzed with paired $t$-tests (2-tailed). $\mathrm{N}=10$ for each species/ location

rence (Figs. 3, 4 \& 5). No consistent feeding deterrent effects were found. However, some of the extracts significantly stimulated fish feeding. Caulerpa sertularioides significantly stimulated fish feeding when tested at 10 and $20 \%$, but not at $5 \%$ (Fig. 3). C. racemosa significantly stimulated fish feeding when the uprights were tested at the low yield of $5 \%$ and the runners at the high yield of $10.8 \%$ (Fig. 4). Both concentrations (1.26 and $20 \%$ ) of the runner extracts of $C$. cupressoides significantly stimulated fish feeding (Fig. 5). Only 1 assay significantly deterred fish feeding and this was $C$. cupressoides, when the uprights were tested at their low yield of $2.5 \%$ (Fig. 5).

Caulerpin and caulerpenyne did not significantly deter grazing by herbivorous fish in either of the 2 types of assays (Enteromorpha clathrata and artificial diet) (Table 5). The no-herbivore controls (which con-

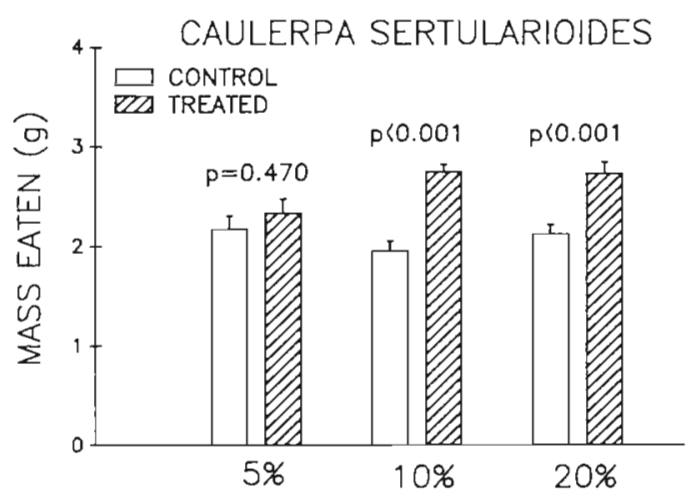

Fig. 3. Results of feeding trials using crude extracts from Caulerpa sertularioides. Test concentrations were chosen to span the natural concentration range. Histograms represent mean food mass eaten, with vertical bars representing $+1 S E$. Data were analyzed using paired t-tests (2-tailed). $\mathrm{N}=20$ paired replicates for each concentration

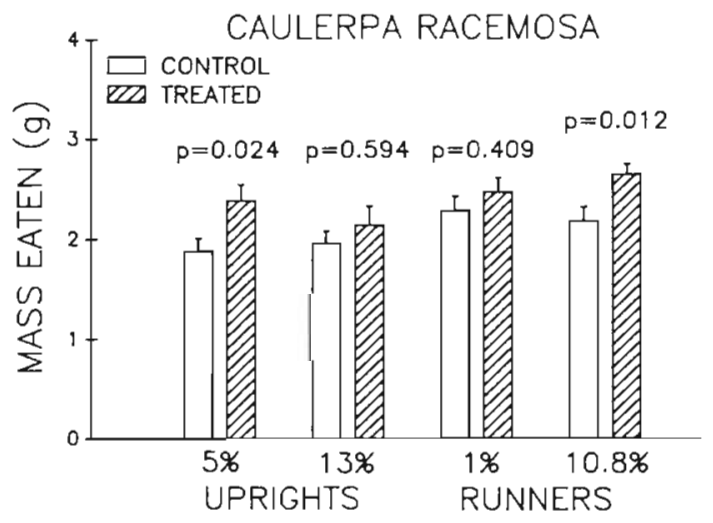

Fig. 4. As in Fig. 3 except using Caulerpa racemosa

sisted of both treatment and control cubes) lost an average of $0.34 \mathrm{~g}$ ( $\mathrm{SE}=0.09 \mathrm{~g}$ ) in mass during the assays. This was a small proportion of the amounts eaten by fishes during the assays. 


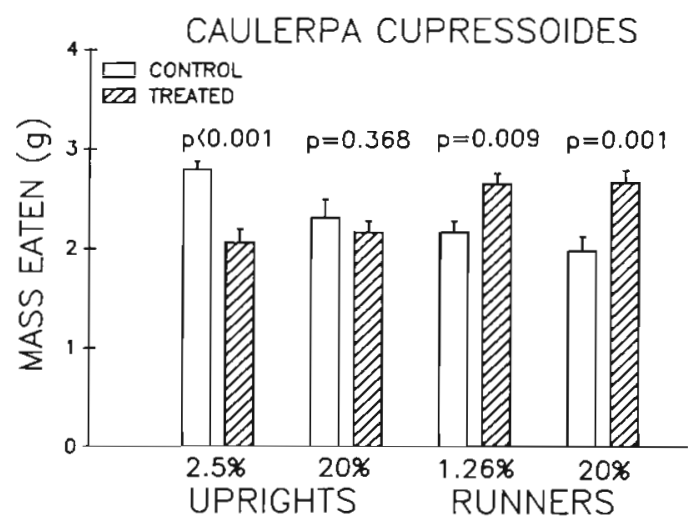

Fig. 5. As in Fig. 3 except using Caulerpa cupressoides

\section{DISCUSSION}

This study demonstrates that there is intraspecific (specifically, intra-plant) variation in the production of secondary metabolites by Caulerpa spp., but it appears that this variation has no effect on the feeding activities of herbivorous fishes. The optimal defense theory predicts that plant parts whose loss would result in the greatest reduction of fitness should be most heavily defended (Feeny 1976, McKey 1979, Nitao \& Zangerl 1987). In Caulerpa spp., sexual reproduction involves the release of gametes from the uprights or blades of the plant (Lee 1989). We predicted that, in order to defend against macroherbivores, the 3 species of
Caulerpa in this study would defend the upright parts that protrude into the water column. Results from this and other studies of intraspecific variation of secondary metabolites in algae have supported optimal defense theory in the sense that the chemistry supports the theory (Phillips \& Towers 1982, Steinberg 1984, Hay et al. 1988, Paul \& Van Alstyne 1988). However, in this case, the ecology of the herbivorous fishes did not support the theory. Different levels of secondary metabolites had no significant effect on the grazing patterns of herbivorous fishes.

Except for one collection of Caulerpa cupressoides, uprights in C. sertularioides, C. racemosa, and $C$. cupressoides consistently contained a higher concentration of organic soluble extract than runners, based on the dry mass of the plant (Table 1). The purified metabolite caulerpenyne also occurred in higher concentrations in the uprights than in the runners (Table 4, Fig. 2). This is interesting given the siphonous nature of the Caulerpa spp. and raises physiological considerations about synthesis, storage, translocation, and induction of these compounds.

Results from the feeding assays toward herbivorous fishes indicate that the observed variation in chemistry did not affect fish feeding. No consistent deterrent effects were noted for crude extracts or pure compounds, and many of the extracts were significant feeding attractants. It is appropriate at this point to review previous studies which have used Caulerpa metabolites in feeding assays. There has been some disagreement as to the chemistry of Caulerpa compounds in the past, but this appears to have been resolved.

Table 5. Results of feeding trials using Caulerpa spp. compounds. Concentrations are based on dry mass and are within the range of natural concentrations

\begin{tabular}{|c|c|c|c|c|c|}
\hline Compound & Assay date & $\begin{array}{l}\text { Control eaten } \pm \mathrm{SE} \\
\text { (g or no. pieces) }\end{array}$ & $\begin{array}{l}\text { Treated eaten } \pm S E \\
\text { (g or no. pieces) }\end{array}$ & $\mathrm{p}$-value & $\mathrm{N}$ \\
\hline \multicolumn{6}{|l|}{ Artificial diet } \\
\hline Caulerpin $3 \%$ & September 18, 1990 & $2.14 \pm 0.13$ & $2.03 \pm 0.11$ & $0.465^{\mathrm{a}}$ & 20 \\
\hline Caulerpenyne $1 \%$ & September 18,1990 & $1.87 \pm 0.14$ & $2.05 \pm 0.14$ & $0.412^{\mathrm{a}}$ & 20 \\
\hline Caulerpenyne $2 \%$ & September 18, 1990 & $1.94 \pm 0.13$ & $1.83 \pm 0.15$ & $0.702^{\mathrm{a}}$ & 20 \\
\hline Caulerpenyne $2.5 \%$ & November 25, 1990 & $2.17 \pm 0.09$ & $1.99 \pm 0.15$ & $0.451^{\mathrm{a}}$ & 12 \\
\hline Caulerpenyne $3 \%$ & September 18, 1990 & $1.68 \pm 0.10$ & $1.74 \pm 0.17$ & $0.762^{a}$ & 20 \\
\hline Caulerpenyne $5 \%$ & November 25, 1990 & $2.25 \pm 0.10$ & $2.48 \pm 0.12$ & $0.219^{2}$ & 20 \\
\hline \multicolumn{6}{|l|}{ Enteromorpha clathrata } \\
\hline Caulerpin $2 \%$ & March 13, 1987 & $2.40 \pm 0.25$ & $3.0 \pm 0.22$ & $0.125^{b}$ & 14 \\
\hline Caulerpenyne $2 \%$ & March 27, 1987 & $3.25 \pm 0.27$ & $2.94 \pm 0.23$ & $0.238^{b}$ & 14 \\
\hline
\end{tabular}


The first compound to be identified from Caulerpa was caulerpicin, by Doty \& Aguilar-Santos (1966). Caulerpenyne was then isolated from a collection of $C$. prolifera (Amico et al. 1978). Caulerpin was isolated from C. racemosa and C. taxifolia collected in Sri Lanka (Maiti et al. 1978). It was then proposed by Paul \& Fenical (1987) that caulerpenyne was the major secondary metabolite comprising Caulerpa extracts and although caulerpin was present, it did not act as a feeding deterrent, as originally thought. Table 6 gives a summary of work that has been done with these 2 compounds and some of the Caulerpa spp. crude extracts to date. To our knowledge, no studies to date have shown that any potential grazer is deterred from feeding on food containing caulerpin. Caulerpicin is a minor component of Caulerpa spp. and appears to be a mixture of several minor compounds (Paul \& Fenical 1987. Paul et al. 1987).

Caulerpenyne has not been consistently deterrent toward all organisms (see Table 6). Our study suggests that, at least on Guam, caulerpenyne does not defend the plants against macroherbivores such as fishes. Instead, it may have other natural functions. Caulerpenyne could be acting as a deterrent toward grazers such as opisthobranch molluscs, urchins, amphipods or herbivorous polychaetes. A study conducted in the Caribbean (McConnell et al. 1982) showed that the urchin Lytechinus variegatus was deterred from grazing by caulerpenyne and the crude extract of Caulerpa prolifera $(\mathrm{p}=0.1)$. Other crude extracts of C. racemosa, C. mexicana, and $C$. ashmeadii were not deterrent. Recent data from Pennings \& Paul (in press) showed that $C$. racemosa crude extract as well as caulerpenyne significantly deterred feeding by the opisthobranch gastropod Dolabella auricularia (Table 6).

Although it is known that ascoglossans such as $O x y$ noe and Volvatella are specialists on Caulerpa spp. (Cimino et al. 1990), no work has been done to measure the impact of these grazers' ecological effects. Volvatella was occasionally seen on the C. cupressoides population sampled, but only on the plants' runners (pers. obs.). However, no plants in this study had Volvatella on them at the time of collection. First, it would be expected that if Volvatella is a significant grazer of the plant, the plant would defend itself by placing defenses in the runners, where the grazer is found. There are several possibilities that could explain why Volvatella occurs on the plant runners, yet higher amounts of secondary metabolites are found in the uprights. It is possible that the Volvatella are attracted

Table 6. Results of previous studies using Caulerpa extracts or pure metabolites

\begin{tabular}{|c|c|c|c|}
\hline $\begin{array}{l}\text { Crude extract or } \\
\text { pure compound }\end{array}$ & Organism used in assay & $\begin{array}{l}\text { Deterrent or } \\
\text { inhibits growth? }\end{array}$ & Source \\
\hline Caulerpenyne & Bacteria & Yes & Paul \& Fenical $(1986,1987)$ \\
\hline Caulerpenyne & Fungi & Yes & Paul \& Fenical $(1986,1987)$ \\
\hline Caulerpenyne & $\begin{array}{l}\text { Lytechinus pictus } \\
\text { Egg cytotoxicity } \\
\text { Larval cytotoxicity }\end{array}$ & $\begin{array}{l}\text { Yes } \\
\text { Yes }\end{array}$ & Paul \& Fenical $(1986,1987)$ \\
\hline Caulerpenyne & Strombus costatus & $55 \%$ dead in $7 \mathrm{~d}$ & Paul \& Fenical (1986) \\
\hline Caulerpenyne & L. variegatus & Yes & McConnell et al. (1982) \\
\hline Caulerpenyne & Dolabella auricularia & Yes & Pennings \& Paul (in press) \\
\hline Caulerpenyne & Damselfish $P$. coeruleus & Yes & Paul \& Fenical $(1986,1987)$ \\
\hline Caulerpenyne & Sparisoma radians & Yes & Targett et al. (1986) \\
\hline Caulerpenyne & Zebrasoma flavescens & No & Wylie \& Paul (1988) \\
\hline Caulerpenyne & Siganus argenteus & No & Paul et al. (1990) \\
\hline Caulerpin & L. variegatus & No & McConnell et al. (1982) \\
\hline Caulerpin & D. auricularia & No & Pennings \& Paul (in press) \\
\hline Caulerpin & Z. flavescens & No & Wylie \& Paul (1988) \\
\hline Caulerpin & S. argenteus & No & Paul et al. (1990) \\
\hline C. serrulata & Guam fish (field) & No & Paul (1987) \\
\hline C. sertularioides & Guam fish (field) & No & Paul (1987) \\
\hline C. prolifera & L. variegatus & Yes & McConnell et al. (1982) \\
\hline C. racemosa & L. variegatus & No & McConnell et al. (1982) \\
\hline C. racemosa & D. auricularia & Yes & Pennings \& Paul (in press) \\
\hline C. racemosa & Guam fish (field) & No & Paul (1987) \\
\hline C. racemosa & Z. flavescens & No & Wylie \& Paul (1988) \\
\hline
\end{tabular}


to the portions of the plant with lower concentrations of secondary metabolites. When plants with Volvatella were extracted, there was a negative correlation between the number of individuals found on the plant and the crude extract yield of the plant (Meyer \& Paul unpubl.). It is also possible that the differences observed in yields are not a response of the plant toward a grazer, but are seen as a result of previous grazing on the plant.

Other small, relatively immobile herbivores such as amphipods and polychaetes, termed mesograzers (Hay et al. 1987), have been predicted to be able to tolerate and live within chemically defended seaweeds as a way of escaping potential predation (Hay et al. 1987. Hay \& Fenical 1988, Hay et al. 1990). A study by Kohn \& White (1977) described herbivorous polychaetes as living in densities of over $40000 \mathrm{~m}^{-2}$ and comprising $16 \mathrm{~g} \mathrm{~m}^{-2}$ dry mass in algal turfs on Guam. Sanddwelling amphipods might also have an effect on algae such as the Caulerpa spp. which send rhizomes and sometimes rhizoids into the substratum. The impact of mesograzers on chemical defense in algae warrants further investigation. Lastly, the pure compounds of the Caulerpa spp. could also be acting as an antifoulant or as protection from ultraviolet light (Zangerl \& Berenbaum 1987). Little work has been done on this aspect of chemical defense with marine algae.

In summary, the results from this study suggest that in the Caulerpa spp. examined in this study, the secondary chemistry of Caulerpa supports optimal defense theory. The portions of the plants that are exposed and involved in sexual reproduction have more secondary metabolites than other portions of the plants. However, the ecology of the plant shows that this chemical variation does not produce 'optimal defense', since the plant is not defended from grazing by herbivorous fishes. Fishes were not deterred from feeding on food that contained secondary metabolites from Caulerpa spp. Further work should focus on the potential role of Caulerpa secondary metabolites as defenses against mesograzers and as antifoulants.

Acknowledgements. We are grateful to students Diane Carangdang-Liberty and Kazu Sonoda for their help. Critical reading by Steve Pennings and several anonymous reviewers greatly improved this manuscript. Support for this research was provided by the University of Hawaii Sea Grant College Program under Institutional Grant No. NA89AA-D-SG063 from NOAA Office of Sea Grant, Dept. of Commerce to V.J.P. HPLC instrumentation was supported by grants from Research Corporation and National Science Foundation (BSR8605299) to V.J.P. We thank William Fenical of Scripps Institute of Oceanography for providing space on the RV Columbus Iselin' research cruise to the Bahamas in July 1990. Funding for research conducted in the Bahamas was provided by National Science Foundation Grant CHE 86-20217 to W. Fenical. This is Contribution no. 318 from the University of Guam Marine Laboratory

\section{LITERATURE CITED}

Amico, V., Oriente, G., Piattelli, M., Tringali, C., Fatturusso, E., Magno, S., Mayol, L. (1978). Caulerpenyne, an unusual sequiterpenoid (sic) from the green alga Caulerpa prolifera. Tetrahedron Lett. 3593

Birkeland, C., Nelson, S. G., Wilkins, S., Gates, P. (1985). Effects of grazing by herbivorous fishes on coral reef community metabolism. In: Gabrie, C. et al. (eds.) Proc. 5th intl. coral Reef Congr. Antenne Museum - EPHE, Moorea, French Polynesia, 4: 47-51

Carlson, D. J., Lubchenco, J., Sparrow, M. A., Trowbridge, C. D. (1989). Fine-scale variability of lanosol and its disulfate ester in the temperate red alga Neorhodomela larix. J. chem. Ecol. 15: 1321-1333

Carpenter, R. C. (1986). Partitioning herbivory and its effects on coral reef algal communities. Ecol. Monogr. 56: 343-363

Cimino, G., Crispino, A., Di Marzo, V., Gavagnin, M., Ros, J. D. (1990). Oxytoxins, bioactive molecules produced by the marine opisthobranch mollusc Oxynoe olivacea from a diet-derived precursor. Experientia 46: 767-770

Doty, M. S., Aquilar-Santos, G. (1966). Caulerpicin, a toxic constituent of Caulerpa. Nature, Lond. 211: 990

Feeny, P. (1976). Plant apparency and chemical defense. Recent Adv. Phytochem. 10: 1-40

Fenical, W. (1982). Natural products chemistry in the marine environment. Science 215: 923-928

Gerwick, W. H., Fenical, W., Norris, J. N. (1985). Chemical variation in the tropical seaweed Stypopodium zonale (Dictyotaceae). Phytochemistry 24: 1279-1283

Hay, M. E., Duffy, J. E., Fenical, W. (1990). Host-plant specialization decreases predation on a marine amphipod: an herbivore in plant's clothing. Ecology 7 (2): 733-743

Hay, M. E., Duffy, J. E., Pfister, C. A., Fenical, W. (1987). Chemical defense against different marine herbivores: are amphipods insect equivalents? Ecology 68 (6): 1567-1580

Hay, M. E., Fenical, W (1988). Marine plant-herbivore interactions: the ecology of chemical defense. A. Rev. Ecol. Syst. 19: 111-145

Hay, M. E., Paul, V. J., Lewis, S. M., Gustafson, K., Tucker, J., Trindell, R. N. (1988). Can tropical seaweeds reduce herbivory by growing at night? Diel patterns of growth, nitrogen content, herbivory, and chemical versus morphological defenses. Oecologia 75: 233-245

Horn, M. H. (1989). Biology of marine herbivorous fishes. Oceangr. mar. Biol. A. Rev. 27: 167-272

Kohn, A. J., White, J. K. (1977). Polychaete annelids of an intertidal reef limestone platform at Tanguisson, Guam. Micronesica 13: 199-215

Lee, R. E. (1989). Phycology, 2nd edn. Cambridge University Press, Sydney

Lewis, S. (1986). The role of herbivorous fishes in the organization of a Caribbean reef community. Ecol. Monogr. 56 (3): $183-200$

Lobban, C. S., Harrison, P. J., Duncan, J. J. (1985). The physiological ecology of seaweeds. Cambridge Univ. Press, New York

Maiti, B. C., Thompson, R. H., Mahendran, M. (1978). The structure of caulerpin, a pigment from Caulerpa algae. J. Chem. Res. 1978: 126-127

McConnell, O. J., Hughes, P. A., Targett, N. M. Daley, J. (1982). Effects of secondary metabolites from marine algae on feeding by the sea urchin, Lytechninus variegatus. J. Chem. Ecol. 8: 1437-1453

McKey, D. (1979). The distribution of secondary compounds within plants. In: Rosenthal, G. A., Janzen, D. H. (eds) 
Herbivores: their interaction with secondary plant metabolites. Academic Press, Sydney, p. 55-133

Morrison, D. (1988). Comparing fish and urchin grazing in shallow and deeper coral reef algal comunities. Ecology 69 (5): $1367-1382$

Nitao, J. K., Zangerl, A. R. (1987). Floral development and chemical defense allocation in wild parsnip (Pastinaca sativa). Ecology 68 (3): 521-529

Ogden, J. C., Lobel, P. S. (1978). The role of herbivorous fishes and urchins in coral reef communities. Environ. Biol. Fish. 3: $49-63$

Paul, V. J. (1985). The natural products chemistry and chemical ecology of tropical green algae of the order Caulerpales. Ph.D. dissertation, Univ. of California, San Diego

Paul, V. J. (1987). Feeding deterrent effects of algal natural products. Bull. mar. Sci. 41 (2): 514-522

Paul, V J., Fenical, W. (1986). Chemical defense in tropical green algae, order Caulerpales. Mar Ecol. Prog. Ser. 34: $157-169$

Paul, V. J., Fenical, W. (1987). Natural products chemistry and chemical defense in tropical marine algae of the Phylum Chlorophyta. In: Scheuer, P. (ed.) Bioorganic marine chemistry, Vol. 1. Springer-Verlag, Berlin, p. 1-29

Paul, V. J., Littler, M. M., Littler, D. S., Fenical, W. (1987). Evidence for chemical defense in tropical green alga Caulerpa ashmeadii (Caulerpaceae: Chlorophyta): isolation of new bioactive sesquiterpenoids. J. chem. Ecol. 13 (5): $1171-1185$

Paul, V. J., Nelson, S. G., Sanger, H. R. (1990). Feeding preferences of adult and juvenile rabbitfish Siganus argenteus in relation to chemical defenses of tropical seaweeds. Mar. Ecol. Prog. Ser. 60: 23-34

Paul, V J., Van Alstyne, K. L. (1988). Chemical defense and chemical variation in some tropical Pacific species of Halimeda (Halimedaceae: Chlorophyta). Coral Reefs 6 : 263-269

Pennings, S. C., Paul, V. J. (in press). Effect of plant toughness, calcification, and chemistry on herbivory by Dolabella auricularia. Ecology

This article was presented by C. Birkeland, Mangilao, Guam
Phillips, D. W., Towers, G. H. N. (1982). Chemical ecology of red algal bromophenols. I. Temporal, intepopulational and within-thallus measurements of lanosol levels in Rhodomela larix (Turner) C. Agardh. J. exp. mar. Biol. Ecol. 58: 285-293

Ragan, M. A., Jensen, A. (1978). Quantitative studies on brown algal phenols. II. Seasonal variation in polyphenol content of Ascophyllum nodosum (L.) Le Jol and Fucus vesiculosus (L.). J. exp. mar. Biol. Ecol. 34: 245-258

Sokal, R. R., Rohlf, F. J. (1981). Biometry, W H. Freeman and Co., New York

Steinberg, P. D. (1984). Algal chemical defense against herbivores: allocation of phenolics compounds in the kelp Alaria marginata. Science 223: 405-407

Steinberg, P. D. (1989). Biogeographical variation in brown algal polyphenolics and other secondary metabolites: comparison between temperate Australasia and North America. Oceologia 78: 373-382

Targett, N. M., Targett, T E., Vrolijk, N. H., Ogden, J. C. (1986). Effect of secondary metabolites on feeding preferences of the herbivorous parrotfish Sparisoma radians. Mar. Biol. 2: 141-148

Tugwell, S., Branch, G. M. (1989). Differential polyphenolic distribution among tissues in kelps, Ecklonia maxima, Laminaria pallida and Macrocystis angustifolia in relation to plant-defence theory. J. exp. mar Biol. Ecol. 129: 219-230

Van Alstyne, K. L. (1988). Herbivore grazing increases polyphenolic defenses in the intertidal brown alga Fucus distichus. Ecology 69 (3): 655-663

Walker, P. M. B. (ed.) (1989). Cambridge dictionary of biology. Cambridge Univ. Press, Sydney, p. 247

Wylie, C. R., Paul, V J. (1988). Feeding preferences of the surgeonfish Zebrasoma flavescens in relation to chemical defenses of tropical algae. Mar. Ecol. Prog. Ser 45: 23-32

Zangerl, A. R., Berenbaum, M. R. (1987). Furanocoumarins in wild parsnip: effects of photosynthetically active radiation, ultraviolet light, and nutrients. Ecology 68: 516-520

Manuscript first received: August 16, 1991

Revised version accepted: March 30, 1992 